\title{
Educational Challenges to Nurses and Nurse Aides of Caring for Diabetic Patients at Home: A Systematic Review
}

\author{
Marzieh Pazokian ${ }^{1}$, Ehsan Daneshmandi ${ }^{*}$, Fereshteh Etemadi ${ }^{1}$ \\ ${ }^{1}$ School of Nursing and Midwifery, Faculty of Nursing, Shahid Beheshti University of Medical Sciences, Tehran, Iran \\ Corresponding Author: Ehsan Daneshmandi, MSc Student in Critical Care Nursing, School of Nursing and Midwifery, Faculty of \\ Nursing, Shahid Beheshti University of Medical Sciences, Tehran, Iran. Tel: +98-9122809736, Email: ehsatila91@gmail.com
}

Received January 17, 2019; Accepted May 25, 2019; Online Published June 15, 2019

\begin{abstract}
Introduction: The prevalence of diabetes among the elderly presents nurses and nurse aides with new challenges to providing high-quality, evidence-based care in nursing homes. Considering the importance of home care, this overview seeks to examine the challenges to organizational home-based care in nursing and nursing patients with diabetes.

Methods: A systematic review of intervention studies from between 2012 and 2016 was conducted using standard and sensitive keywords such as: "development," "implementation," "evaluation," "education," "diabetes patient," "home care," and "nursing homes" with other possible word combinations, such as advancement, assessment, nursing care providers, and home care centers. The databases searched included PubMed, Science Direct, Ovid, Wiley, and Scholar. The articles which met the inclusion criteria and quality standards for this study were selected for review.

Results: Out of 543 retrieved articles, seven articles were analyzed in a case study. Three articles showed the professional development of nurses, the exchange of their experiences, professional self-confidence, increased professional development, and improved communication between care-provider and caregivers.

Conclusions: Now more than ever, the lack of continuous training in treatment and care plays a pivotal role among teaching staff as a basic requirement for reducing the incidence of complications of diabetes among individuals, especially the elderly. Getting to know more about the benefits of severe glycemic control in people with advanced disease can help achieve therapeutic goals.

Keywords: Challenges, Expansion, Implementation, Evaluation, Training Programs, Patients with Diabetes, Nursing Care Nurses, Nurses Citation: Pazokian M, Daneshmandi E, Etemadi F. Educational challenges to nurses and nurse aides of caring for diabetic patients at home: a systematic review. Int J Med Rev. 2019;6(2):65-72. doi:10.29252/IJMR-060207.
\end{abstract}

\section{Introduction}

The elderly population around the world is growing, and acceptance of the fact that most elderly people want to continue living in their homes means an increase in home care. ${ }^{1}$ Home care providers need to have the competence to identify and address the patient's care needs. The implementation of a person-centered assessment in home care services can go a long way in dealing with patients' care needs today. ${ }^{2}$ As the prevalence of diabetes increases among elderly people, nurses and nurse aides face challenges in providing high-quality, evidence-based care in nursing homes. Today, the lack of follow-up care and treatment has highlighted staff training as a basic requirement. Organizational challenges related to the transfer of tasks from specialist to primary care services increase the need for professional qualifications. ${ }^{3}$

The 2014 UK Diabetes Home Health Inspection reported a lack of evaluation, monitoring, and special care for people with diabetes who live in nursing homes and special care centers. Many nursing homes do not systematically screen patients with diabetes, and many do not even control blood glucose levels in diabetic patients. Staffs are not educated or trained correctly, and patients are at risk of hypoglycemia and complications of diabetes mellitus. The diabetes institute called for more elaborate caregivers for older people to overcome this problem. ${ }^{4}$ Our estimates encounter decision makers with a better understanding of the burden of diabetes in nursing homes in each state. These estimates can be considered as vital input for planning and evaluating diabetes prevention and management interventions, which will allow people to live healthier and longer in their communities. ${ }^{5}$

\footnotetext{
Methods

Design

A systematic overview was carried out using existing guidelines for identifying quantitative data. Clear objectives and obvious criteria were selected, and the search strategy for identifying articles was determined. Then, the selected studies were analyzed, and the results of randomized controlled trials were combined.
}

Copyright (C) 2019 The Author(s). This is an open-access article distributed under the terms of the Creative Commons Attribution License (http:// creativecommons.org/licenses/by/4.0), which permits unrestricted use, distribution, and reproduction in any medium, provided the original work is properly cited. 


\section{Research Methodology}

A systematic review of studies was done on the challenges facing nurses and nurse aides of teaching nursing care for diabetic residents at nursing homes based on the resources and documents available in English, nondomestic resources and documents published between the years 2012-2018. The 7 -step Cochran's model was followed for specifying the year, determining the inclusion criteria, selecting studies, assessing the quality of studies, extracting data, and analyzing and presenting the results. To find studies published in this field, articles published in foreign journals on PubMed, Science Direct, Ovid, Wiley, and Scholar databases were reviewed. A systematic search was performed using keywords such as "challenge," "extension," "implementation," "evaluation," "education," "patient with diabetes," "home care," and "nursing home" with other possible word combinations, such as progression, assessment, nursing care providers, and home care providers. In addition, the bibliographies of the identified studies were reviewed to find more relevant articles. First, a list of titles and a summary of all the articles in the above databases were prepared. The related articles were individually included in the research cycle. Entry criteria included various research articles, including review articles and systematic reviews that were consistent with the current research and challenged the development, implementation, and evaluation of diabetes education for nurses and home nurses. The included articles were in English and covered a 6-year period from 2012 to 2018 . Exclusion criteria were nonresearch articles with no relevance to the subject matter, nonEnglish-language articles, articles published prior to 2012, non-scientific journals, organizational posters, and articles providing training for diabetic patients for nurses in hospital environments.

\section{Search Results}

In total, 543 articles were selected based on the terms "implantation," "education," "diabetes patients," and "home care." Thirty-five duplicate articles were deleted, and 487 cases were eliminated due to inadequate processing or lack of attention to the place of training for diabetic patients. Then, 21 articles on the implementation of nursing education in patients with diabetes in nursing homes were reviewed. Of the 21 relevant records identified, 6 records were omitted from the full-text evaluation due to poor content quality. Eventually, 17 records were included in the qualitative integration. After a thorough evaluation of the remaining articles, 10 articles were omitted due to qualitative statistical methods. Ultimately, 7 papers of quantitative and interventional files were selected based on the entry criteria and were used in the systematic final examination (Figure 1).

\section{Quality Evaluation}

The included studies address the educational challenges of nursing care for patients with diabetes for nurses and nurse aides at nursing home-based situations. The 10 qualitative indicators used to evaluate each study are presented in Table 1. Seven studies met the admission criteria and were included in this systematic review.

\section{Data Abstract}

Table 2 was prepared using the criteria set for entering the study. Key points studied in this study were study design,

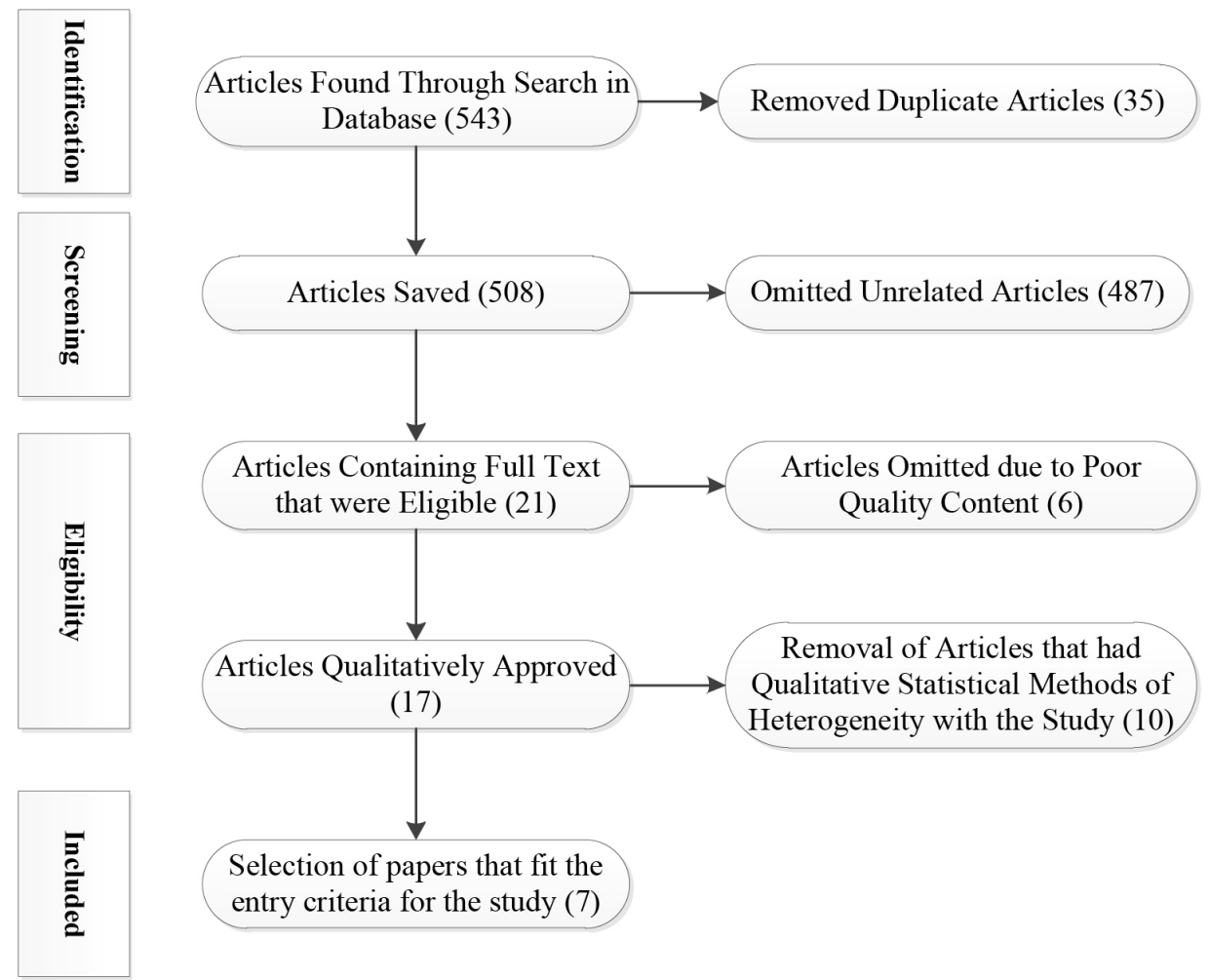

Figure 1. PRISMA 2009 Flow Diagram. 
Table 1. Information From 10 Articles Related to Educational Challenges for Care of Diabetic Patients at Home; for Nurses and Nurse Aides

\begin{tabular}{|c|c|c|c|c|c|c|c|c|}
\hline Study \& Origin & Design & $\begin{array}{l}\text { Sample } \\
\text { Size }\end{array}$ & $\begin{array}{l}\text { Age } \\
\text { Group }\end{array}$ & $\begin{array}{l}\text { Focused } \\
\text { Research } \\
\text { Question }\end{array}$ & $\begin{array}{l}\text { Selection/ } \\
\text { Allocation }\end{array}$ & $\begin{array}{l}\text { Power Calculation/ } \\
\text { Analysis }\end{array}$ & $\begin{array}{c}\text { Baseline } \\
\text { Comparability } \\
\text { Groups }\end{array}$ & $\begin{array}{l}\text { Confounding } \\
\text { Factors } \\
\text { Considered }\end{array}$ \\
\hline $\begin{array}{l}\text { Yarnall et al } \\
(2012),{ }^{6} \text { Newcastle, } \\
\text { UK }\end{array}$ & $\begin{array}{l}\text { Existing care against these } \\
\text { standards }\end{array}$ & $31 / 7$ & Elderly & Yes & $\begin{array}{l}\text { Random group } \\
\text { allocation ( } 31 \\
\text { patients) }\end{array}$ & $\begin{array}{l}\text { Too small size; } \\
\text { semi-qualitative and } \\
\text { semi-quantitative } \\
\text { study; SPSS-17 }\end{array}$ & Yes & Yes \\
\hline $\begin{array}{l}\text { Vajen et al (2012), } \\
\text { Ohio, West } \\
\text { Virginia, USA }\end{array}$ & $\begin{array}{l}\text { Diabetes management in } \\
\text { nursing homes }\end{array}$ & $245 / 14$ & Elderly & Yes & $\begin{array}{l}\text { Random group } \\
\text { allocation ( } 245 \\
\text { patients) }\end{array}$ & $\begin{array}{l}\text { Version } 14.0 \text { (SPSS, } \\
\text { Chicago, IL) }\end{array}$ & Yes & Yes \\
\hline $\begin{array}{l}\text { Hausken and Graue } \\
(2013),{ }^{3} \text { Norway }\end{array}$ & $\begin{array}{l}\text { Professional upgrading, } \\
\text { exchange of experiences, } \\
\text { professional nurses' self- } \\
\text { esteem }\end{array}$ & 20 & $32-59$ & Yes & $\begin{array}{l}\text { Selective group } \\
\text { allocation }\end{array}$ & $\begin{array}{l}\text { Too small size; } \\
\text { questionnaire } \\
\text { contained both } \\
\text { quantitative and } \\
\text { qualitative data }\end{array}$ & Yes & Yes \\
\hline $\begin{array}{l}\text { Munshi et al } \\
(2016),{ }^{8} \text { USA }\end{array}$ & $\begin{array}{l}\text { Increased financial burden } \\
\text { of diabetes }\end{array}$ & $\begin{array}{c}\text { Not } \\
\text { mentioned }\end{array}$ & Adult & No & Not given & Not given & Not given & Yes \\
\hline $\begin{array}{l}\text { American Diabetes } \\
\text { Association } \\
(2015),{ }^{12} \text { USA }\end{array}$ & $\begin{array}{l}\text { Diabetes management in } \\
\text { long-term nursing care }\end{array}$ & $\begin{array}{l}\text { Not } \\
\text { mentioned }\end{array}$ & Elderly & Yes & Not given & Standard guidelines & Yes & Yes \\
\hline $\begin{array}{l}\text { Walfridsson et al } \\
(2016),{ }^{10} \text { Sweden }\end{array}$ & $\begin{array}{l}\text { Evaluating the status of } \\
\text { elderly patients with } \\
\text { diabetes in nursing homes } \\
\text { for the care of the elderly }\end{array}$ & $1350 / 30$ & Elderly & Yes & $\begin{array}{l}\text { Random group } \\
\text { allocation }\end{array}$ & $\begin{array}{l}\text { Independent Sample } \\
\text { t-test }\end{array}$ & Yes & Yes \\
\hline $\begin{array}{l}\text { Haugstvedt et al } \\
(2016),{ }^{11} \text { Norway }\end{array}$ & $\begin{array}{l}\text { A survey of providing } \\
\text { high quality health care in } \\
\text { nursing home }\end{array}$ & 127 & Adult & Yes & $\begin{array}{l}\text { Selected sample } \\
\text { selection ( } 32 \\
\text { registered nurses, } \\
69 \text { nurses, } 26 \text { nurse } \\
\text { aides) }\end{array}$ & $\begin{array}{l}\text { ANOVA } \\
\text { ANCOVA }\end{array}$ & Yes & Yes \\
\hline
\end{tabular}

validation of actions, and evaluation time.

\section{Synthesis}

The assessment key was the descriptive result, the design of the studies, the validation of the evaluation, and the duration of the evaluation. Key required data was extracted from the papers and recorded on the information form which included general information about the article (title and year of study), study characteristics (clinical fields, methodology, and type of study), and results of the studies. The findings were therefore summarized in narrative form rather than using direct comparison.

\section{Results}

Characteristics of the Studies

The findings of a systematic review on the challenges of education of caring for diabetic patients for nurses and nurse aides at home were analyzed. The studies had been published in several journals between 2012 and 2016 and included Yarnall et al, ${ }^{6}$ Vajen et al, ${ }^{7}$ Hausken and Graue, ${ }^{3}$ Munshi et al, ${ }^{8}$ American Diabetes Association, ${ }^{9}$ Walfridsson et al, ${ }^{10}$ and Haugstvedt et al. ${ }^{11}$ The publication date of the seven analytical studies showed that we are facing a relatively common and important issue in nursing research, i.e. the challenges of nursing home care provided by nurses and nurse aides (Table 2). In seven analytical studies, 1773 samples were studied. A cross-sectional study (Walfridsson et $\mathrm{al}^{10}$ ) and a comparative study (Vajen et $\mathrm{al}^{7}$ ) were also included. In this research, two issues were investigated: (1) Analysis of the challenges of care education for diabetic patients; (2) Abilities of nurses and nurse aides to care for patients with diabetes after receiving care education.

Interventions to Address the Educational Challenges for Nurses and Nurse Aides of Caring for Diabetic Patients at Home

In 5 studies, the case groups were elderly diabetic patients who received nursing intervention, including nursing education. In 2 other studies, nurses were instructed to care for patients with diabetes. In these 2 studies, the promotion of professionalism, the exchange of experiences, professional self-confidence, increased professional development, improved communication in careers and levels of care, and reflections based on experience with patients and perceived challenges in clinical practice of sharing knowledge and individual improvements were the aims for nurses and nurse aides who care for diabetic patients at long-term home care facilities. In addition, participants in these two studies reported self-esteem in relation to evidence-based practice skills and knowledge and the provision of highquality nursing care. Consequently, it seems that the elements of this program are sufficient to plan for the promotion of professional competence of nurses and nurse aides in the care of elderly diabetic patients. Annual follow-up meetings as part of the services provided by specialized health care services should be completed on a regular basis. In five other studies, the need for new care standards was proposed for diabetic patients living in nursing homes. These standards 
Pazokian et al

Table 2. Results and Evidence of Research, Education Challenges of Caring for Diabetic Patients at Home; for Nurses and Nurse Aides

\begin{tabular}{|c|c|c|c|c|c|c|}
\hline Study & Clinical Theme & $\begin{array}{l}\text { Interventions in } \\
\text { research }\end{array}$ & Comparator & Assessment measures & Interventions in research & $\begin{array}{l}\text { Effect of training on the performance of } \\
\text { nursing personnel }\end{array}$ \\
\hline $\begin{array}{l}\text { Hausken and } \\
\text { Graue }(2013)^{3}\end{array}$ & $\begin{array}{c}\text { Extending, implementing, and assessing } \\
\text { effect of education on diabetic patients } \\
\text { for nurses and nurse aides at nursing } \\
\text { homes }\end{array}$ & $\begin{array}{l}\text { Sixteen registered } \\
\text { nurses and four } \\
\text { nurses participated } \\
\text { in the study } \\
\text { (women aged 32- } \\
60 \text { ). }\end{array}$ & $\begin{array}{l}\text { Enhancing professional development; } \\
\text { improving communication in careers } \\
\text { and level of care; and reflections } \\
\text { based on experience with patients } \\
\text { and perceived challenges in clinical } \\
\text { practice }\end{array}$ & $\begin{array}{l}\text { Participants reported confidence in the skills } \\
\text { and knowledge of evidence-based practice and } \\
\text { provided high-quality nursing care. }\end{array}$ & & $\begin{array}{l}\text { Proof of the adequacy of the elements } \\
\text { of this program for planning to improve } \\
\text { nursing professional competence and } \\
\text { nurses' aides in the care of elderly dia- } \\
\text { betics; } \\
\text { Conduct regular annual follow-up meet- } \\
\text { ings as part of the services provided by } \\
\text { specialized health care services }\end{array}$ \\
\hline $\begin{array}{l}\text { Munshi et al } \\
(2016)^{8}\end{array}$ & $\begin{array}{l}\text { Diabetes management in long-term care } \\
\text { and professional nursing care facilities }\end{array}$ & & $\begin{array}{l}\text { In long-term care, there is a higher } \\
\text { prevalence of complications of } \\
\text { diabetes, with a more severe fiscal } \\
\text { burden. The risk of hypoglycemia } \\
\text { is the most important factor in } \\
\text { determining the goals of glycemic } \\
\text { patients due to the catastrophic } \\
\text { consequences of this population. }\end{array}$ & $\begin{array}{l}\text { Simplified home-based regimens are preferred } \\
\text { and the use of variable-rate insulin (SSI) should } \\
\text { be avoided. As these patients are moved from } \\
\text { one treatment environment to another at home or } \\
\text { from their care providers, the risk of side effects } \\
\text { increases as well. }\end{array}$ & $\begin{array}{l}\text { Reducing the risk of hypoglycemia } \\
\text { and ultimately improving the } \\
\text { quality of life }\end{array}$ & $\begin{array}{l}\text { Understanding the features, challenges, } \\
\text { and barriers of diabetic elderly living in } \\
\text { nursing homes; a better understanding of } \\
\text { the proper functioning of these facilities; } \\
\text { identifying the challenges; individual } \\
\text { approaches can be designed to improve } \\
\text { the management of diabetes. }\end{array}$ \\
\hline $\begin{array}{l}\text { American } \\
\text { Diabetes } \\
\text { Association } \\
(2015),{ }^{12} \text { USA }\end{array}$ & Medical standards for diabetes & $\begin{array}{l}\text { The American } \\
\text { Medical Staff } \\
\text { Association's guide } \\
\text { offers a 12-step } \\
\text { curriculum for } \\
\text { long-term nursing } \\
\text { care for staff at } \\
\text { home. }\end{array}$ & $\begin{array}{l}\text { Diabetic elderly living in nursing } \\
\text { homes are more vulnerable to the } \\
\text { risk of a lowering of blood sugar } \\
\text { due to a lack of proportionality in } \\
\text { the incidence of a higher number of } \\
\text { complications and co-morbidities } \\
\text { with several diseases. }\end{array}$ & $\begin{array}{l}\text { Alert strategies for blood glucose (blood glucose } \\
\text { less than } 70 \mathrm{mg} / \mathrm{dL} \text { or } 3.9 \mathrm{mmol} / \mathrm{L} \text { ) or increased } \\
\text { blood glucose (blood glucose greater than } 250 \\
\mathrm{mg} / \mathrm{dL} \text { or } 13.9 \mathrm{mmol} / \mathrm{L} \text { ) should be considered. }\end{array}$ & $\begin{array}{l}\text { Particular attention should be paid } \\
\text { to nutrition considerations, end-of- } \\
\text { life care, and diabetes management } \\
\text { in those with advanced disease, } \\
\text { for caregivers in nursing homes. } \\
\text { Understanding the benefits of } \\
\text { limiting glycemic control in people } \\
\text { with advanced disease can guide } \\
\text { A1C's goals and determine the use } \\
\text { or withdrawal of medications from } \\
\text { treatment. }\end{array}$ & \\
\hline
\end{tabular}




\begin{tabular}{|c|c|c|c|c|c|c|}
\hline Study & Clinical Theme & $\begin{array}{l}\text { Interventions in } \\
\text { research }\end{array}$ & Comparator & Assessment measures & Interventions in research & $\begin{array}{l}\text { Effect of training on the performance of } \\
\text { nursing personnel }\end{array}$ \\
\hline $\begin{array}{l}\text { Walfridsson et al } \\
(2016)^{10}\end{array}$ & $\begin{array}{l}\text { Investigating the status of elderly } \\
\text { diabetic patients in nursing homes for } \\
\text { the care of the elderly; considering } \\
\text { the treatment of diabetes, the clinical } \\
\text { variables, and vascular complications } \\
\text { associated with diabetes; evaluating } \\
\text { patients at risk for hypoglycemia in } \\
\text { home care nursing homes }\end{array}$ & $\begin{array}{l}\text { Current anti- } \\
\text { diabetic drugs, } \\
\text { HbA1c, blood } \\
\text { glucose events, } \\
\text { and diabetes } \\
\text { complications were } \\
\text { recorded from the } \\
\text { medical records } \\
\text { of home care } \\
\text { patients. Patients } \\
\text { were divided into } \\
\text { three subgroups } \\
\text { in a general group } \\
\text { based on HbA1c } \\
\text { (less than } 52 \text {, } \\
\text { between } 52 \text { and } 73, \\
\text { and greater than } 73 \\
\text { mmol). }\end{array}$ & $\begin{array}{l}\text { Duration of diabetes and serum } \\
\mathrm{HbA} 1 \mathrm{C}\end{array}$ & $\begin{array}{l}\text { Approximately } 80 \% \text { of diabetic patients had } \\
\text { microvascular side effects, and the duration of } \\
\text { diabetes was a correlation between microvascular } \\
\text { side effects and glucose-lowering events. }\end{array}$ & & $\begin{array}{l}\text { Based on the findings of this study, } \\
\text { reduced use of anti-diabetic drugs with } \\
\text { follow-up on HbA1c levels, especially } \\
\text { for elderly patients with multiple } \\
\text { illnesses, with low HbA1c levels, and } \\
\text { often symptoms of low blood sugar, } \\
\text { should be taken into account in the care } \\
\text { of home care workers. }\end{array}$ \\
\hline $\begin{array}{l}\text { Haugstvedt et } \\
\text { al }{ }^{11}(2016)\end{array}$ & $\begin{array}{l}\text { Assessing the provision of high-quality } \\
\text { health care in nursing homes and } \\
\text { home care centers and the need for } \\
\text { appropriate tools for assessing the level } \\
\text { of knowledge of diabetes among health } \\
\text { care providers. }\end{array}$ & $\begin{array}{l}\text { This study included } \\
127 \text { nursing staff } \\
\text { (32 registered } \\
\text { nurses, } 69 \text { nurses, } \\
\text { and } 26 \text { nurse aides) } \\
\text { in three nursing } \\
\text { homes and a home } \\
\text { care center in } \\
\text { Norway. }\end{array}$ & $\begin{array}{l}\text { The psychometric properties of the } \\
\text { Michigan Diabetes Knowledge Test } \\
\text { are reviewed for use by nursing staff. }\end{array}$ & $\begin{array}{l}\text { Measurement of items based on the theory of } \\
\text { response and the information curve item; the } \\
\text { maximum information is shown in the mean or } \\
\text { low scores of knowledge and awareness. The } \\
\text { internal consistency item and case correlations } \\
\text { were quite weak, indicating that the Michigan } \\
\text { Diabetes Knowledge Test meets a set of related } \\
\text { issues related to knowledge but not necessarily to } \\
\text { each other. }\end{array}$ & & $\begin{array}{l}\text { The University of Michigan test is } \\
\text { an appropriate tool for identifying } \\
\text { the individual and distinct needs of } \\
\text { diabetes education among nursing staff. } \\
\text { The knowledge gap identified by the } \\
\text { Michigan Diabetes Knowledge Test can } \\
\text { provide useful information for presenting } \\
\text { educational content. }\end{array}$ \\
\hline $\begin{array}{l}\text { Vajen et al } \\
(2012)^{7}\end{array}$ & $\begin{array}{l}\text { Comparison of care for diabetic patients } \\
\text { in long-term nursing care centers with } \\
\text { American Diabetes Association's Care } \\
\text { Standards }\end{array}$ & $\begin{array}{l}\text { In this study, } \\
\text { medical diagnoses, } \\
\text { medications, } \\
\text { laboratory reports, } \\
\text { and counseling } \\
\text { recorded over the } \\
\text { past year in patients } \\
\text { with home-based } \\
\text { diabetes were } \\
\text { reviewed and } \\
\text { compared with the } \\
\text { American Diabetes } \\
\text { Association's care } \\
\text { standards }\end{array}$ & $\begin{array}{l}\text { In this case study, } 245 \text { residents from } \\
14 \text { care centers were screened. All } \\
\text { of these patients had a documented } \\
\text { medical diagnosis of type } 1 \text { or type } \\
2 \text { diabetes and had spent at least } \\
3 \text { years at one of these home care } \\
\text { centers. }\end{array}$ & $\begin{array}{l}\text {-Glucose monitoring } \\
\text { Control } \\
\text { - HA1C control } \\
\text {-LDL control } \\
\text { Hyperglycemia events } \\
\text { Hypoglycemia events } \\
\text {-Eye observations }\end{array}$ & $\begin{array}{l}\text { The results of this study suggest the } \\
\text { need for new care standards for } \\
\text { diabetic patients living in nursing } \\
\text { homes. These standards should be } \\
\text { considered according to the specific } \\
\text { needs of this patient population, } \\
\text { with special regard to the risk of } \\
\text { hypoglycemia, cardiovascular risk } \\
\text { factors, and quality of life. }\end{array}$ & \\
\hline
\end{tabular}


should be considered according to the specific needs of this target group, with special regard to the risk of hypoglycemia, cardiovascular risk factors, and quality of life.

\section{Evidence of Effectiveness}

The results of Yarnell et al suggest that while nursing care is provided at home nursing care facilities in New Zealand, inappropriate management was also evidenced. Despite high levels of dementia, many patients have robust and credible opinions about illness and its control. Despite the challenges ahead, we believe that residents of this home care facility should be included in the discussion of development of services. ${ }^{6}$

Based on the results of their research, Vajen et al suggest the need for new care standards for diabetic patients living in nursing homes. These standards should be considered according to the specific needs of this vulnerable group, with special regard to the risk of hypoglycemia, cardiovascular risk factors, and quality of life. ${ }^{7}$

The results of Hausken and Graue's research indicated that nurses' professional promotion, the exchange of their experiences, professional self-confidence, increased professional development, improved communication in careers and levels of care, experience-based reflections on patients and understanding challenges in clinical trials, knowledge sharing and individual development, increasing self-esteem in relation to the skills and knowledge of evidence-based practice, providing high-quality nursing care, and planning for the promotion of professional competence for nurses and nurse aides in the care of elderly people with diabetes are sufficient and may be followed up with annual follow-up meetings. Part of the services provided by specialized health care services will be completed on a regular basis. $^{3}$

The results of the study by Munshi et al revealed that it is important that care providers recognize the characteristics, challenges, and barriers of elderly people living in nursing homes as well as the proper functioning of these facilities. Once these challenges are identified, individual approaches can be designed to improve diabetes management while reducing the risk of hypoglycemia and ultimately improving quality of life. ${ }^{8}$

The investigations of the American Association for Diabetes found that practical guidelines are needed for healthcare providers as well as caregivers and home care providers. The American Medical Staff Association's Guide suggests a 12-step curriculum for long-term nursing care providers at home. Particular attention should be paid to nursing considerations, end-of-life care, and diabetes management in those with advanced disease for caregivers in nursing homes. Understanding the limited benefits of severe glycemic control in people with advanced disease can guide the treatment staff to reach the preset goals for $\mathrm{A} 1 \mathrm{C}$ and determine the use or withdrawal of drugs from treatment. ${ }^{9}$

According to a study by Walfridsson et al, the use of antidiabetic drugs with follow-up on HbAlc levels, especially for elderly patients with low-grade HbAlc levels and often with symptoms of hypoglycemia, should be taken into account by the caregiver staff at home. ${ }^{10}$ The study of Haugstvedt et al found that the Michigan Diabetes Knowledge Test addresses a wide range of topics related to diabetes care. This is an appropriate tool for identifying the individual and distinct needs of diabetes education among nursing staff. The knowledge gap identified by the Michigan Diabetes Knowledge Test can provide useful information for presenting educational content. However, brief revisions to the test should be considered. ${ }^{11}$

\section{Discussion}

The current study purposed to investigate the educational challenges of caring for diabetic patients at home for nurses and nurse aides. This study challenges the prevalence of diabetes, the prevention of its complications among elderly people, and the actions of nurses and nurse aides in providing high-quality, evidence-based care in nursing homes. Various studies have been conducted on the challenges of nursing home care of diabetic patients for nurses and nurse aides, but each of these studies has yielded different results; only some of them have a common end point. Today, the lack of follow-up care and treatment has highlighted staff training as an essential requirement in reducing the incidence of diabetes mellitus, especially among the elderly in nursing homes. In these studies, there was no single conclusion on the educational challenges in nursing homes for diabetic patients for nurses and nurse aides; however, in all of the studies, the effect of training for nurses and nurse aides on reducing the incidence of complications in people with diabetes at home has been specially considered.

Many limitations in studies such as Hugstudt et al and Hausken and Graue regarding blood glucose control, Hemoglobin A1C control, eye exam, and foot health examinations in the early diagnosis and prevention of complications of diabetes as a benefit of nursing education were seen. ${ }^{3,11}$

The practical and clinical guidelines for residents receiving nursing care that were provided by Yarnell et al also target less the blood glucose levels in elderly diabetic patients as the basis of nursing care as a result of education provided to the medical staff. ${ }^{6}$ In this study, $77 \%$ of the diabetic patients residing in this house were affected by possible dementia (based on psychological test scores); their weight, body mass index, and blood pressure were satisfactory. On the other hand, blood glucose monitoring was unnecessarily performed in all residents, but not especially for those with diabetes (63\%) who were under close dietary control. The majority of residents $(90 \%)$ were visited by a chiropodist to diagnose the early onset of diabetic foot ulcers, and more than $80 \%$ of them received eye screening examinations. Only one of the care homes had employees who had passed diabetes education. In this study, at least one or more trained nurses and members of the nursing staff who have undergone diabetes care education in nursing homes have been emphasized. ${ }^{6}$

The study by Munshi et al states that diabetes is more common among the elderly and is associated with prolonged long-term care, a high financial burden of illness, and higher costs associated with treatment that can be significantly 
reduced by educating the medical staff. The heterogeneity of this population is necessary due to the simultaneous comorbidity of several diseases, the general health conditions for determining personal goals, and the spread of diabetes treatment. The risk of hypoglycemia is the most important factor in determining the goals of glycemic patients due to the catastrophic consequences of inadequate training in this population. The use of simple diet regimens is preferable, and the use of sliding scale insulin (SSI) should be avoided. As these patients are transferred from a specialized healthcare environment to another simple environment or their care providers are changed, the risk of side effect incidences increases. The strategies are proposed to reduce these risks and ensure that patients are securely transported from complex hospital settings to home-care centers and homebased health care environments. For care providers, it is important to understand the characteristics, challenges, and barriers of elderly people living in nursing homes and the proper functioning of these facilities. The limitations in the focus were on the education of nurses and nurse aides in this observation. $^{8}$

Walfridsson et al who assessed the status of elderly diabetic patients in nursing homes for the care of the elderly and an article by the American Diabetes Association titled "Diabetes Management in Long-Term Care Nursing in Nursing Home" both shared common goals. ${ }^{10,12}$ In the study of Walfridsson et al, the use of common antidiabetic drugs, HbA1c and blood glucose levels, and diabetes complications were documented in patient medical records. Blood glucose loss due to lack of nursing and medical stuff education was reported in $24 \%$ of diabetics, with only $43.1 \%$ of them having an HbA1c of less than $52 \mathrm{~mm} / \mathrm{L}^{10}$

Of these patients, $36 \%$ consumed anti-diabetic drugs without instructional emphasis on the precise use of the drugs at a specified time and continuous prescription; $35.8 \%$ of the other patients had HbAlc values between 52-73 mg (mean $=60 \pm 1.60 \mu \mathrm{m}$ ), and $82 \%$ of those were taking anti-diabetic drugs. Approximately $80 \%$ of diabetic patients without proper education had microvascular or macrovascular side effects, and the duration of diabetes was considered as a correlation between microvascular and macrovascular side effects and hypoglycemic events. ${ }^{10}$ On the other hand, the American Medical Staff Association's guidelines propose a 12-step curriculum for long-term care nursing staff at home. Elderly patients with diabetes residents at nursing homes are more vulnerable to hypoglycemia events due to inappropriate proportion between morbidity to more complications and concomitant illnesses associated with several diseases.

Alert strategies for blood glucose (less than $70 \mathrm{mg} / \mathrm{dL}$ or $3.9 \mathrm{mmol} / \mathrm{L}$ ) or increased blood glucose (greater than 250 $\mathrm{mg} / \mathrm{dL}$ or $13.9 \mathrm{mmol} / \mathrm{L}$ ) levels should be considered when staff are being trained. Particular attention should be paid to nutritional considerations, end-of-life care, and diabetes management in those with advanced disease in order to educate caregivers in nursing homes. Learning more about the benefits of severe glycemic control in people with advanced disease can help achieve A1C's goals and determine the use or withdrawal of drugs from treatment. ${ }^{9}$
The limitations in assessing the educational challenges of caring for diabetic patients at home for nurses and nurse aides can be cited as the shortcomings in these two recent studies. ${ }^{10,12}$ Restriction of the study by Hugstudt et al. (2016) was also considered. In this study provision of high-quality health care in nursing homes and home care centers; and also the need for appropriate tools for assessing the level of diabetes knowledge among health care providers who were not aware of the specific parameters of diabetes control; were investigated. They aimed to study the psychometric properties of the Michigan Diabetes Test for Testing, which was used among the nursing staff. This study included 127 nursing staff ( 32 registered nurses, 69 nurses, and 26 nurse aides) in three nursing homes and a home care center in Norway. In examining the findings, relevant and appropriate cases were used in both general diabetes and sub-assays of insulin use. This tool showed satisfactory properties for detection between groups. The results of this study showed that the Michigan Diabetes Knowledge Test meets a wide range of topics related to diabetes care education. ${ }^{11}$

On the other hand, Vajen et $\mathrm{al}^{7}$ conducted a study comparing the management of diabetes mellitus among residents of longterm care centers with the American Diabetes Association's outpatient care standards. In this case study, 245 residents from 14 care centers were screened. All of these patients had a medical documented diagnosis of type 1 or type 2 diabetes and had spent at least 3 years at one of these home care centers. In their study, medical diagnoses, medications, laboratory reports, and counseling over the past year were reviewed, and then their findings were compared with the American Diabetes Association's care standards. Results from 245 patients showed that $211(86.1 \%)$ patients monitored their blood glucose through self-care training provided by nursing staff. Only 52 patients living in these care centers (21.2\%) had experienced hypoglycemic events, and 103 patients (42\%) had experienced an increase in blood glucose levels. Of the 240 patients $(98 \%)$ who had their blood pressure monitored, 107 (43.7\%) had self-care goals under the influence of the American Diabetes Association. Eye tests were performed in 133 patients $(54.3 \%)$.

Foot health tests were performed on 187 patients in these care centers $(76.3 \%) ; 170$ patients $(69.4 \%)$ consulted with a chiropodist. In examining the results of the charts, it was seen that managing diabetes in long-term care centers for many outpatients does not meet the American Diabetes Association's self-care training standards. Although $36.7 \%$ of patients achieved the ideal goals for A1C values, the A1C was not responsible for the variability in blood glucose levels. Only $46.8 \%$ of patients achieved predetermined goals for LDL.

The results of this study suggest there is an urgent need for training new standards for the care of diabetic patients living in nursing homes. These educational standards should be considered according to the specific needs of this population, with special regard to the risk of hypoglycemic events, cardiovascular risk factors, and quality of life. ${ }^{7}$ Given the lack of such studies in Iran, the limited number of clinical trials conducted on this subject, the fact that such studies are conducted exclusively in Europe and the United States, and 
the various ways to determine the effects of such studies on the challenges of nursing home care for nurses and nurse aides, the need for further studies in this area is significant. More comprehensive studies addressing wider issues in which the effects of educating nurses and nurse aides on preventing and reducing the complications of diabetes in the elderly and identifying the symptoms of these complications should be considered as soon as possible.

It is clear that the transfer from acute care setting for all patients, not just those with diabetes or newly diagnosed hyperglycemia, is a high-risk period. Although there is widespread literature on the transmission of patients inside and outside the hospital, only part of it is dedicated to diabetes. ${ }^{13}$

Patients may be cared for after being discharged from a hospital setting in various centers, such as home (with or without referral to nursing services) or an assisted living facility. For patients discharged from the hospital who are continuing care in nursing homes or at home, an optimal diabetes treatment plan will be needed based on the type and severity of diabetes, the effects of the illness on blood glucose levels, and the patient's capacity and needs.

Outpatient follow-up visits are recommended with primary care providers, endocrinologists, or trained diabetes educators within one month of the discharge date for all patients who have had high blood sugar during hospitalization. Providing clear contact with outpatient care providers, either directly or through a briefing facility that is provided at clearance time, provides safe transportation from the hospital environment to the home environment. Providing information about causes of high blood glucose (or a plan to determine the cause of diabetes), related complications, associated illnesses, and recommended treatments, would provide continues cares for diabetic outpatients. ${ }^{12}$

\section{Conclusions}

Teaching care of diabetic patients in nursing homes, longcare nursing homes, nursing home care centers, and assisted living facilities has attracted a lot of attention in recent years, and it seems that there is still more research in the field of identifying effective and influential factors in the field of educational challenges for nursing personnel to be done. In all studies, the significant effect of the role of nursing education on the reduction of complications in diabetic patients at home has been considered. The need for new care standards for diabetic patients living in nursing homes should be considered according to the particular needs of this vulnerable group, with special regard to the risk of hypoglycemia, cardiovascular risk factors, and quality of life. In recent researches, at least one or more of the trained nurses or nursing staff who have received diabetes care education in nursing homes have been emphasized. Diabetes is more common among the elderly and is more prevalent in the issue of long-term care with a high financial burden and higher medical costs, which can be significantly reduced by educating caregivers in care. Training for treatment personnel is one of the most important pillars of treatment today; however, in Iran, it has been less addressed in various aspects than other components of treatment.
Since the prevalence of diabetes and high blood sugar in Iran are increasing, and given the close connection between the lack of effective training for people with diabetes or those at risk for it and the fact that the occurrence of complications resulting from this secondary illness is the lack of compliance with methods of controlling such complications, it is clearly suggested that extensive studies should be carried out on the epidemiological aspects of the use of education, the use of experienced personnel in the training of nursing staff and nurse aides, and on the strategies delivering practical training in plain and intelligible language to the target group of this disease in Iran.

\section{Authors' Contributions}

All authors contributed equally to this study.

\section{Conflict of Interest Disclosures}

The authors declare they have no conflicts of interest.

\section{References}

1. Mentsen Ness T, Hellzen O, Enmarker I. The Experience of Nurses Providing Home Nursing Care to Oldest Old Persons Living Alone in Rural Areas-An Interview Study. Open J Nurs. 2015;5(4):336-344. doi:10.4236/ojn.2015.54036.

2. Anker-Hansen C, Skovdahl K, McCormack B, Tonnessen S. The third person in the room: The needs of care partners of older people in home care services-A systematic review from a person-centred perspective. J Clin Nurs. 2018;27(7-8):e1309-e1326. doi:10.1111/jocn.14205.

3. Hausken MF, Graue M. Developing, implementing and evaluating diabetes care training for nurses and nursing aides in nursing homes and municipal home-based services. European Diabetes Nursing. 2013;10(1):19-24b. doi:10.1002/edn.219.

4. Anderson P. Managing diabetes in nursing and care homes. Nurs Times. 2014;110(34-35):20-21.

5. Neuwahl SJ, Honeycutt AA, Poehler DC, Shrestha SS, Zhang P, Hoerger TJ. Diabetes-attributable nursing home costs for each US state. Diabetes Care. 2018;41(7):1455-1461. doi:10.2337/dc172028.

6. Yarnall AJ, Hayes L, Hawthorne GC, Candlish CA, Aspray TJ. Diabetes in care homes: current care standards and residents' experience. Diabet Med.2012;29(1):132-135.doi:10.1111/j.1464-5491.2011.03393.x.

7. Vajen BM, Holt R, Marx T, Schwartz FL, Shubrook JH. How well are we managing diabetes in long-term care? J Fam Pract. 2012;61(8):467472.

8. Munshi MN, Florez H, Huang ES, et al. Management of diabetes in long-term care and skilled nursing facilities: a position statement of the American Diabetes Association. Diabetes Care. 2016;39(2):308318. doi:10.2337/dc15-2512.

9. American Diabetes Association. Standards of medical care in diabetes - 2016 abridged for primary care providers. Clin Diabetes. 2016;34(1):3-21. doi:10.2337/diaclin.34.1.3.

10. Walfridsson A, Sehlberg M, Gillespie U, Dahlkvist J, Johansson HE. Diabetes treatment and hypoglycaemic episodes in elderly patients at nursing homes in Uppsala County. Ups J Med Sci. 2016;121(3):179183. doi:10.1080/03009734.2016.1198441.

11. Haugstvedt A, Aarflot M, Igland J, Landbakk T, Graue M. Diabetes knowledge in nursing homes and home-based care services: a validation study of the Michigan Diabetes Knowledge Test adapted for use among nursing personnel. BMC Nurs. 2016;15:40. doi:10.1186/ s12912-016-0159-1.

12. American Diabetes Association. Diabetes care in the hospital, nursing home, and skilled nursing facility. Diabetes Care. 2015;38 Suppl:S80-85. doi:10.2337/dc15-S016.

13. Shepperd S, Lannin NA, Clemson LM, McCluskey A, Cameron ID, Barras SL. Discharge planning from hospital to home. Cochrane Database Syst Rev. 2013(1):Cd000313. doi:10.1002/14651858. CD000313.pub4. 